INTERNATIONAL JOURNAL
PHARMACEUTICAL SCIENCES
RESEARCH
RESTI

Received on 11 March 2019; received in revised form, 22 June 2019; accepted, 27 June 2019; published 01 July 2019

\title{
ISOLATION, SCREENING AND CHARACTERIZATION OF L-ARGINASE PRODUCING SOIL BACTERIA
}

\author{
P. D. Nadaf, A. G. Kulkarni and A. B. Vedamurthy *
}

PG Department of Biotechnology and Microbiology, Karnatak University, Dharwad - 580003, Karnataka, India.

\begin{tabular}{l} 
Keywords: \\
L-Arginase, \\
Screening, 16s rRNA \\
sequencing, Pseudomonas sp. \\
\hline Correspondence to Author: \\
Prof. A. B. Vedamurthy \\
Professor, \\
P G Department of Biotechnology \\
and Microbiology, Karnatak University, \\
Dharwad - 580003, Karnataka, India. \\
E-mail: vedamurthybt@gmail.com
\end{tabular}

\begin{abstract}
L-arginase (EC 3.5.3.1) is a therapeutic enzyme which catalyzes the hydrolysis of L-arginine to L-ornithine and urea. L-arginase is of keen interest due to its significance as an anti-cancer mediator against auxotrophic cancers. This enzyme is widely distributed and expressed in organisms like fungi, plants, non-chordates, and chordates, however very scarce report is available for L-arginase from bacteria. Therefore, the present study was aimed to isolate L-arginase producing bacteria from soil. Soil samples were collected from different locations in and around Karnatak University campus, Dharwad, Karnataka, India. L-arginase activity was confirmed by rapid plate assay screening using minimal arginine agar media and estimating the urea level colorimetrically. Among the sixty-eight isolates, twenty-nine of them were positive for the L-arginase production, but, the most potent isolate was selected, characterized, and identified in our study. The isolate was identified as Pseudomonas sp. strain PV1 (GenBank accession number MK459549.1).
\end{abstract}

INTRODUCTION: L-arginase (EC 3.5.3.1) is a ureohydrolase enzyme that catalyzes L-arginine to ornithine and urea ${ }^{1}$. It is a crucial enzyme in the urea cycle, which facilitates the organism in detoxifying ammonia and excretion of excess nitrogen from the system ${ }^{2}$. It is widely distributed and expressed in different organisms ${ }^{3}$. L-arginase regulates the cellular levels of arginine through these metabolic pathways i. Regulates the level of L-arginine for the production of nitric acid, ii. Regulates the level of L-ornithine for the production of L-proline and polyamines to form collagen and facilitate cell growth and repair, respectively ${ }^{4,5}$. L-arginase occurs in two forms in mammalian tissues, i.e., L-arginase I and II, which are coded by the genes located on chromosome 6 and 14 respectively ${ }^{6}$.

\begin{tabular}{|l|c|}
\hline QUICK RESPONSE CODE & DOI: \\
\hline DOI link: http://dx.doi.org/10.13040/IJPSR.0975-8232.10(7).3440-44 \\
\hline
\end{tabular}

L-arginase has been reported to play a crucial role in the treatment of neurological disorders ${ }^{7}$, allergic asthma ${ }^{8}$, rheumatoid arthritis ${ }^{9}$, it is also found to have tumor inhibitory properties and has been accredited substantial consideration due to its extensive range of activity against cancer cells ${ }^{10}$. Certain cancers cannot biosynthesize arginine due to lack of expression of argininosuccinate synthetase-1 (ASS1).

These cancers require arginine for proliferation and metastasis. L-arginine is catabolized into Lornithine and urea. Nutritional starvation due to lack of L-arginine leads to inhibition of DNA, RNA, and proteins biosynthesis, ultimately resulting in apoptosis of cancer cells. Normal cells can synthesize arginine due to which remain unaffected ${ }^{11,12}$. This resulted in a persistent attempt to screen newer organisms to find strains capable of fabricating new L-arginase with great yield and fewer adverse properties. L-arginase has considerable anticancer potential; there are only a few investigations for sources of production of this enzyme. 
Mammalian arginase ${ }^{13}$ has been characterized well, relatively a very few reports on prokaryotic arginase have been characterized ${ }^{14}$ such as Bacillus brevis $^{15}$, B. anthraci ${ }^{16}$, and Helicobacter pylori ${ }^{17}$. Studies of the enzyme from fungi, Neurospora crassa ${ }^{1}$, Aspergillus nidulans ${ }^{18}$ and Penicillium chrysogenum 10 have been reported. Microorganisms can be easily cultivated and manipulated due to which they are considered a good source for the production of enzymes ${ }^{19}$. Anticancer enzymes from micro-organisms are of keen interest because of their specific activity and stability at various physiological parameters. However, not much work has done on the isolation of $\mathrm{L}$ - arginase from bacteria. Hence, the present investigation deals with the isolation, screening, and identification of most potent L-arginase producing bacteria from soil.

\section{MATERIALS AND METHODS:}

Collection of Soil Samples: Soil samples were collected in sterile polythene bags from different locations in and around Karnatak University campus, Dharwad, Karnataka, India, and stored at $4^{\circ} \mathrm{C}$ until further use.

\section{Isolation and Screening of L-arginase Producing} Bacteria: Soil samples were serially diluted, spread on the nutrient agar plates and incubated at $37^{\circ} \mathrm{C}$ for $24-48 \mathrm{~h}$. Bacterial colony morphology was studied, examined for microscopic and biochemical characters and subjected for further screening. Bacterial strains were sub-cultured on nutrient agar slants every 15 days.

Isolates were screened for L-arginase activity by streaking on minimal media constituting: $\mathrm{KCl}$ $0.5 \%, \mathrm{MgSO}_{4} 0.5 \%, \mathrm{KH}_{2} \mathrm{PO}_{4} 1.0 \%, \mathrm{FeSO}_{4} 0.1 \%$, $\mathrm{ZnSO}_{4} 0.1 \%$, L-arginine (HiMedia, India) $1.0 \%$, and fluconazole $(20 \mu \mathrm{g} / \mathrm{ml}){ }^{20}$. In the present study, the media was further modified using phenol red $2 \%$ in our laboratory. The inoculated plates were incubated for $48 \mathrm{~h}$ at $37^{\circ} \mathrm{C}$. The isolates which turned media to pink were positive and were selected for further screening.

Estimation of L-arginase Activity: The positive isolates were fermented in the media with composition: glucose $1 \%$, peptone $0.5 \%$, yeast extract $0.5 \% \quad \mathrm{~K}_{2} \mathrm{HPO}_{4} 0.1 \%$, L-arginine $0.5 \%$, $\mathrm{pH}$ 7.0 and the flask were incubated in an incubator shaker at $120 \mathrm{rpm}$ at $37^{\circ} \mathrm{C}$ for $96 \mathrm{~h}^{21}$. Samples were withdrawn at regular intervals of $24 \mathrm{~h}$ for determination of enzyme activity.

L-arginase activity was determined based on the amount of urea released in the reaction. Urea on heating reacts with $\alpha$-isonitrosopropiophenone (Sigma-Aldrich, India) in the presence of ethanol produces a pink color which was estimated colorimetrically ${ }^{22}$. The reaction mixture consisted of $0.2 \mathrm{ml}$ of glycine buffer ( $\mathrm{pH} 9.0), 0.5 \mathrm{ml}$ of an enzyme, and $0.1 \mathrm{ml}$ of $\mathrm{MnCl}_{2}$. L-arginase was activated by incubating at $37^{\circ} \mathrm{C}$ for $10 \mathrm{~min}$. Larginine hydrolysis was achieved by incubating the activated arginase with $0.1 \mathrm{ml}$ of L-arginine at $37^{\circ} \mathrm{C}$ for $30 \mathrm{~min} 1 \mathrm{ml}$ of perchloric acid was added to arrest the reaction. The urea liberated was estimated by addition of $0.1 \mathrm{ml}$ of $4 \% \alpha$ isonitrosopriopophenone at $540 \mathrm{~nm}$.

Enzyme activity $(\mathrm{U} / \mathrm{ml})=\mu$ moles of urea released /Time of enzyme action $\times$ Volume of the enzyme $(\mathrm{ml})$

\section{Characterization and Identification of Potent} Bacterial Isolate Producing L-arginase: The potent isolate was identified based on morphological and biochemical characters by Bergey's Manual of Systematic Bacteriology ${ }^{23}$. Further molecular characterization was carried out by16s rRNA sequencing at Agarkar Research Institute, Pune.

\section{RESULTS AND DISCUSSION:}

Isolation and Screening of L-arginase Producing Bacteria: A total of sixty-eight bacterial isolates were isolated from different soil samples and used for various screening studies.

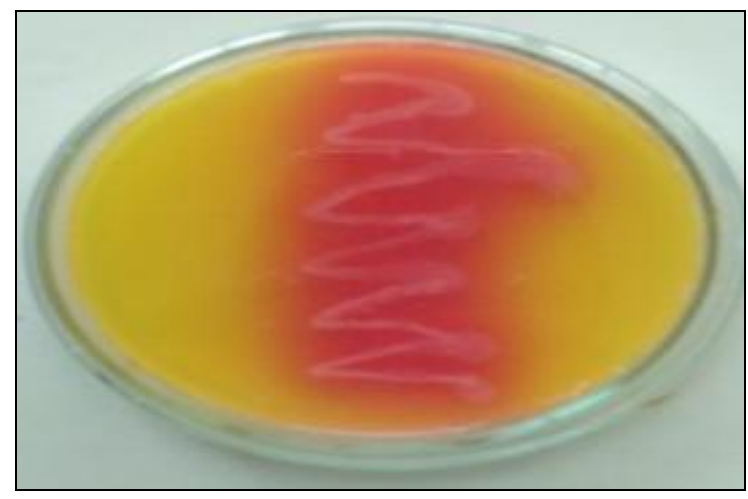

FIG. 1: ISOLATE SHOWING POSITIVE RESULT FOR THE PRODUCTION OF L-ARGINASE

The current study involved the screening of isolated bacteria, on minimal arginine agar media with arginine as the sole source of nitrogen and 
carbon, in which only the organisms that were able to utilize nitrogen and carbon could grow ${ }^{16,24}$. In our study, the minimal media was further supplemented with phenol red as indicator and fluconazole as an anti-fungal agent. Phenol red dye in media at acidic $\mathrm{pH}$ is yellow, which turns pink at alkaline $\mathrm{pH}$. The presence of a pink colored zone around the colonies on plates is due to the liberation of arginase ${ }^{21}$. In the current study, twenty-nine isolates showed a pink zone around the colonies, indicating that they produce L-arginase.

Quantification of L-arginase: So far, the reports for L-arginase from bacterial sources are poorly characterized relative to those from animals ${ }^{25}$ or plants ${ }^{26}$. In the present investigation, among the twenty-nine isolates, bacterial isolate 20 showed the highest activity of $34.86 \mathrm{U} / \mathrm{ml}$ at $24 \mathrm{~h}$. All other strains in this study exhibited maximum activity at 48 h. Previous studies have reported highest Larginase activity of Bacillus thuringiensis SK 20.001, and Rummeliibacilus pycnus SK31.001 was $8.4 \mathrm{U} / \mathrm{ml}^{21}$ at $24 \mathrm{~h}$ and $40.2 \mathrm{U} / \mathrm{ml}^{27}$ at $16 \mathrm{~h}$ respectively with an optimal temperature of $80^{\circ} \mathrm{C}$. Comparatively, our isolate has shown better results at $37^{\circ} \mathrm{C}$, which indicates that it can be easily cultured and its high productivity reveals that this organism could be a good candidate for the Larginase production.

\section{Identification and Characterization of the Most}

Potent Bacteria: The morphological and biochemical characteristics of isolate 20, which showed highest L-arginase activity Table $\mathbf{1}$ and $\mathbf{2}$, indicated that the organism belonged to the genus Pseudomonas. Molecular characterization by $16 \mathrm{~s}$ rRNA sequencing revealed that it has about $99 \%$ similarity with Pseudomonas sp. strain SB743. Hence, the strain was confirmed as Pseudomonas sp. strain PV1 (GenBank accession number MK459549.1).

TABLE 1: COLONY AND MORPHOLOGICAL CHARACTERISTICS OF ISOLATE 20

\begin{tabular}{cc}
\hline Characters & Results \\
\hline Size & Small \\
Shape & Circular \\
Elevation & Flat \\
Appearance & Shiny \\
Texture & Rough \\
Margin & Entire \\
Pigmentation & Pigmented \\
Gram Staining & + ve rod \\
\hline
\end{tabular}

TABLE 2: BIOCHEMICAL CHARACTERISTICS OF ISOLATE 20

\begin{tabular}{cc}
\hline Tests & Results \\
\hline Indole & $-\mathrm{ve}$ \\
Methyl red & $-\mathrm{ve}$ \\
Voges-Proskauer & $-\mathrm{ve}$ \\
Citrate utilization & $+\mathrm{ve}$ \\
Gelatin hydrolysis & $+\mathrm{ve}$ \\
Catalase & $+\mathrm{ve}$ \\
Oxidase & $+\mathrm{ve}$ \\
Amylase production & $-\mathrm{ve}$ \\
Cellulose production & $-\mathrm{ve}$ \\
Casein production & $+\mathrm{ve}$ \\
Hydrogen sulfide production & $-\mathrm{ve}$ \\
\hline
\end{tabular}

Phylogenetic Analysis: Based on the Tamura-Nei model, evolutionary history was inferred using Maximum likelihood method ${ }^{28}$. The tree with the highest log likelihood (-2073.31) is shown. Mega7 was used to conduct evolutionary analysis ${ }^{29}$.

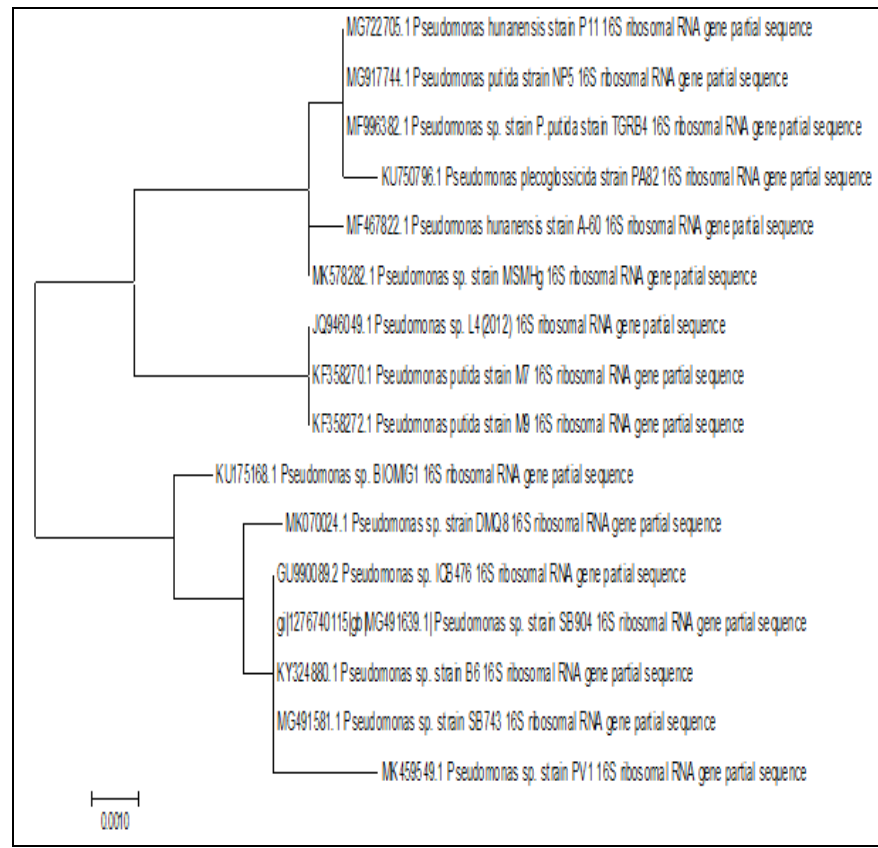

FIG. 2: MOLECULAR PHYLOGENETIC ANALYSIS BY MAXIMUM LIKELIHOOD METHOD

CONCLUSION: L-arginase is a biocatalyst of choice for the present and future, owing to its unique properties and a key enzyme in pathophysiology with novel therapeutic roles. Very scarce literature is available regarding the isolation, screening of L-arginase from bacteria. Hence, in the present investigation, L-arginase producing bacteria were isolated from soil and tested on the minimal media with slight modification using phenol red as indicator and fluconazole as an antifungal agent which makes the observation more conspicuous. 
Based on L-arginase activity, the most potent strain was identified to be Pseudomonas sp. strain PV1. Further, enzyme optimization, purification of Larginase from bacteria can be exploited for profound therapeutic benefits in the treatment of various physiological disorders in the body. The use of L-arginase as a potential chemotherapeutic agent could show a lot of potential and promise in the coming years.

ACKNOWLEDGEMENT: The authors are thankful to the PG Department of Biotechnology and Microbiology, Karnatak University, Dharwad, for providing all the necessary facilities and University Grants Commission Maulana Azad National Fellowship for awarding fellowship for the year 2016-17.

\section{CONFLICT OF INTEREST: Nil}

\section{REFERENCES:}

1. Borkovich KA and Weiss RL: Purification and characterization of arginase from Neurospora crassa. Journal of Biological Chemistry 1987; 262: 7081-86.

2. Jenkinson CP, Grody WW and Cederbaum SD: Comparative properties of arginases. Comparative Biochemistry and Physiology-Part B Biochemistry and Molecular Biology 1996; 114: 107-32.

3. Dzik JM: Evolutionary roots of arginase expression and regulation. Frontiers in Immunology 2014; 5: 1-11.

4. Hwang JH, Kim HE and Cho DY: Isolation and properties of arginase from a shade plant, ginseng (Panax ginseng C.A. Meyer) roots. Phytochemistry 2001; 58: 1015-24.

5. Mori $\mathrm{M}$ and Gotoh T: Arginine. Metabolic enzymes, nitric oxide and infection. Journal of Nutrition 2004; 134: 2820S-2825S.

6. Wu G and Moris JSM: Arginine metabolism: Nitric oxide and beyond. Biochemical Journal 1998; 336: 1-17.

7. Esch F, Lin KI, Hills A, Zaman K, Baraban JM, Chatterjee S, Rubin L, Ash DE and Ratan RR: Purification of a multipotent anti-death activity from bovine liver and its identification as arginase: nitric oxide-independent inhibition of neuronal apoptosis. The Journal of Neuroscience 1998; 18: 4083-95.

8. Maarsingh $\mathrm{H}$ and Meurs $\mathrm{H}$ : Arginase: a key enzyme in the pathophysiology of allergic asthma opening novel therapeutic perspectives. British Journal of Pharmacology 2009; 158: 652-64.

9. Corraliza I and Moncada S: Increased expression of arginase II in patients with different forms of arthritis. Implications of the regulation of nitric oxide. The Journal of Rheumatology 2002; 29: 2261-65.

10. El-Sayed AS, Shinida AA, Diab AA and Rady AM: Purification and immobilization of L-arginase from thermotolerant Penicillium chrysogenum KJ185377.1; with unique kinetic properties as a thermostable anticancer enzyme. Archives of Pharmacal Research 2014; 37: 1-10.

11. Cavanaugh PG and Nicolson GL: Partial purification of a liver-derived tumor cell growth inhibitor that differentially inhibits poorly-liver metasizing cell lines: Identification as an active subunit of arginase. Clinical \& Experimental Metastasis 2000; 18: 509-18.

12. Philip R, Campbell E and Wheatley DN: Arginine deprivation, growth inhibition and tumor cell death: 2 . Enzymatic degradation of arginine in normal and malignant cell cultures. British Journal of Cancer 2003; 88: 613-23.

13. Munder M: Arginase: An emerging key player in the mammalian immune system. British Journal of Pharmacology 2009; 158: 638-51.

14. Zolfaghar M, Amoozegar MA, Khajeh K, Babavalian H and Tebyanian $\mathrm{H}$ : Isolation and screening of extracellular anticancer enzymes from halophilic and halotolerant bacteria from different saline environments in Iran. Molecular Biology Reports, 2019; 1-12.

15. Kanda M, Ohgishi K, Hanawa T and Saito Y: Arginase of Bacillus brevis Nagano: Purification, properties, and implication in gramicidin $\mathrm{S}$ biosynthesis. Archives of Biochemistry and Biophysics 1997; 344: 37-42.

16. Viator RJ, Rest RF, Hildebrandt E and McGee DJ: Characterization of Bacillus anthracis arginase: effects of $\mathrm{pH}$, temperature, and cell viability on metal preference. BMC Biochemistry 2008; 9: 1-14.

17. Zhang J, Zhang X, Wu C, Lu D, Guo G, Mao X, Zhang Y, Wang DC, Li D and Zou Q: Expression, purification and characterization of arginase from Helicobacter pylori in its apo form. PLoS One 2011; 6: 1-8.

18. Borsuk P, Dzikowska A, Empel J, Grzelak A, Grzeskowiak R and Weglenski P: Structure of the arginase coding gene and its transcript in Aspergillus nidulans. Acta Biochimica Polonica 1999; 46: 391-03.

19. Kumar D and Sobha K: L-Asparaginase from microbes: a comprehensive review. Advances in Bioresearch 2012; 3: 137-57.

20. Unissa R, Sudhakar M and Reddy AS Selective isolation and molecular identification of L-arginase producing bacteria from marine sediments. World Journal of Pharmacy and Pharmaceutical Sciences 2015; 4: 998-06.

21. Zhang T, Guo Y, Zhang H, Mu W, Miao M and Jiang B: Arginase from Bacillus thuringiensis SK 20.001: Purification, characteristics, and implications for Lornithine biosynthesis. Process Biochemistry 2013; 48: 663-668.

22. Archibald RM: Colorimetric determination of urea. Journal of Biochemistry1945; 157: 507-518.

23. Sneath PHA, Mair NS, Sharpe ME and Holt JG: Bergey's manual of systematic bacteriology. Williams \& Wilkins, Second Edition 2001.

24. Kumar K, Phathak T and Walia S: L-arginase based biosensor for detection of L-arginine in juice samples. Journal of Natural Product and Plant Resources 2012; 2: 494-99.

25. Hirsch-Kolb H, Greenberg DM: Molecular characteristics of rat liver arginase. The Journal of Biological Chemistry 1968; 243: 6123-29.

26. Krumpelman PM, Freyermuth SK, Cannon JF, Fink GR and Polacco JC: Nucleotide sequence of Arabidopsis thaliana arginase expressed in yeast. Plant Physiology 1995; 107: 1479-80.

27. Haung $\mathrm{K}$, Zhang $\mathrm{T}$, Jiang $\mathrm{B}, \mathrm{Mu} \mathrm{W}$ and Miao $\mathrm{M}$ : Characterization of a thermostable arginase from Rummeliibacillus pycnus SK31.001. Journal of Molecular Catalysis B: Enzymatic 2016; 133: S68-S75.

28. Tamura $\mathrm{K}$ and Nei M: Estimation of the number of nucleotide substitutions in the control region of mitochondrial-DNA in humans and chimpanzees. Molecular Biology and Evolution 1993; 10: 512-26. 
29. Kumar S, Strecher G and Tamura K: MEGA7: Molecular datasets. Molecular Biology and Evolution 2016; 33: evolutionary genetics analysis version 7.0 for bigger 1870-74.

How to cite this article:

Nadaf PD, Kulkarni AG and Vedamurthy AB: Isolation, screening and characterization of L-arginase producing soil bacteria. Int J Pharm Sci \& Res 2019; 10(7): 3440-44. doi: 10.13040/IJPSR.0975-8232.10(7).3440-44.

All $\odot 2013$ are reserved by International Journal of Pharmaceutical Sciences and Research. This Journal licensed under a Creative Commons Attribution-NonCommercial-ShareAlike 3.0 Unported License.

This article can be downloaded to Android OS based mobile. Scan QR Code using Code/Bar Scanner from your mobile. (Scanners are available on Google Play store) 